\title{
A new concept for an old instrument: flexible corneal scrapping spatula
}

\section{Um novo conceito para um antigo instrumento: espátula corneana flexível}

Acacio Lima Filho ${ }^{(3)}$

Paulo Schor ${ }^{(1)}$

Maria Cecília Zorat Yu ${ }^{(2)}$

Ana Luisa Hofling de Lima ${ }^{(2)}$
From the Bioengineering ${ }^{(1)}$ and Laboratory ${ }^{(2)}$ Sections Ophthalmology Department - Federal University of São Paulo, and Ophthalmos Microbiology Laboratory ${ }^{(3)}$.

Endereço para correspondência: AcacioLima Filho - Universidade Federal de São Paulo - UNIFESP Departamento de Oftalmologia - Rua Botucatú, 822 CEP 04023-062 - São Paulo-SP.

\begin{tabular}{|c|}
\hline SUMMARY \\
\hline $\begin{array}{l}\text { We describe a new methods to produce an instrument to scrap } \\
\text { the cornea. It is made from either a fine needle or a cannula. The } \\
\text { material is flattened by means of a laminator or a hammer and a flat } \\
\text { metal surface. A sandpaper is used to rough the front end and round } \\
\text { it. The tip is slightly bent and the device is submitted to ethylene } \\
\text { oxide for sterilization. A handle may be used to hold the instrument, } \\
\text { which may be reusable, after washing and sterilization using local } \\
\text { heat at the tip, or gas. }\end{array}$ \\
\hline
\end{tabular}

Keywords: Spatula; Microbiology; Diagnosis; Bioenginee-ring; Cornea.

\section{INTRODUCTION}

Spatulas are used to scrap the corneal stroma and epithelium, specially in infectious diagnostic procedures. They need to be flexible, small and reusable instruments, useful to produce cultures, and direct examinations of fresh material extracted from (mainly) an infected lesion at the corneal surface. These devices were made of platinum, carved into, a thin and curve shape. Heat may be applied for the sterilization of these devices. Since the original concept of Kimura's spatula ${ }^{1,2}$, few modifications were added to the device and technique. In fact the material was replaced by an ordinary metal (i.e. iron), that often degrades after several heatings, leading to a dirty smear. In addition, this metal did not have the useful flexibility of platinum.

With the advent of less expensive resistant disposable materials, i.e. stainless steel needles and cannulas (Figure 1), it is possible to manufacture a new instrument, that preserves the classic concepts, that is, being flexible, thin, small and reusable.

\section{METHODS}

Two ways of producing the device are presented: with the aid of a laminator, or a hammer and a metal surface. The first consists of grasping the needle (or cannula) between two flat hard metal rollers (Figure 2). It is rolled half an inch and rolled back. The needle is therefore flattened. Sandpaper is gently applied to the sharp tip (of the needle) to rough and round it (Figure 3). The tip is bent to the desired angle, and sent to gas sterilization. The second way replaces the laminator with a hammer and a flat metal surface (Figure 4). The needle is successively hit to produce a flat surface. Sandpaper and oxide sterilization follow in the same manner as described above. A handle may be used to ease the manipulation. Figure 5 shows the whole process from the cannula to the mounted instrument. 


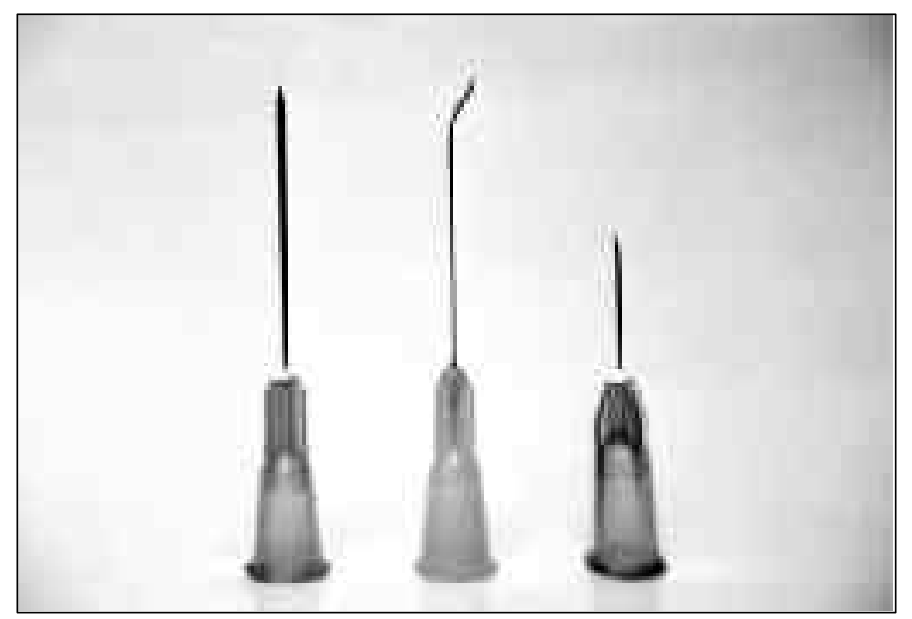

Fig. 1 - Needle (left and right) and cannula used to produce the instrument

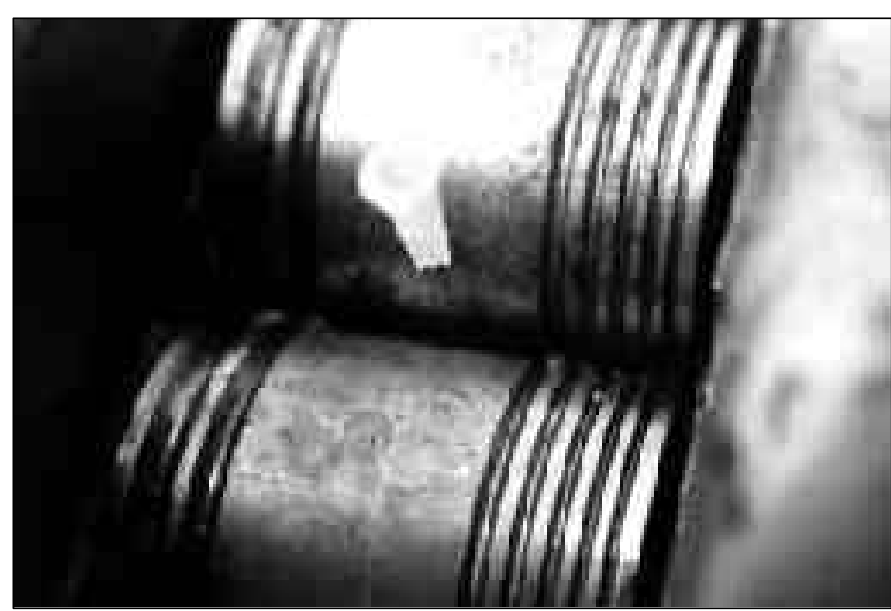

Fig. 2 - Grasping a needle betwen two metal roler (Iaminator)

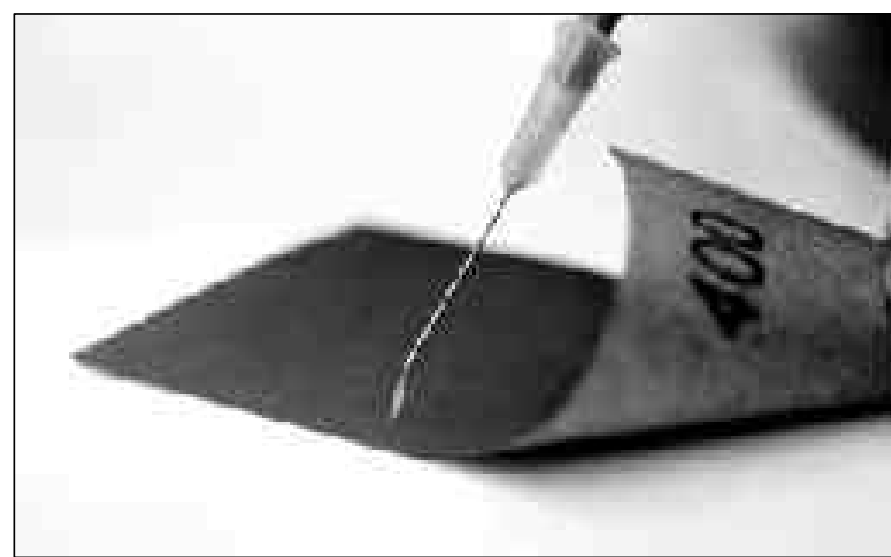

Fig. 3 - Sandpaper is used to rough and round the produced tip

\section{RESULTS}

Although the sharper quality of the new device might interfere in the spreading of the material, and care must

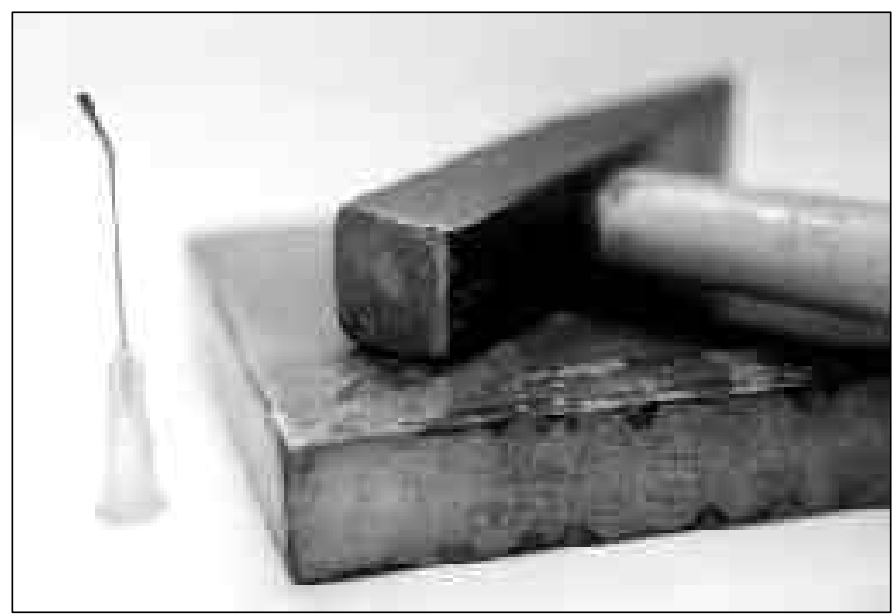

Fig. 4-Alternative way to produce the instrument, using a hammer and a flat metal surface

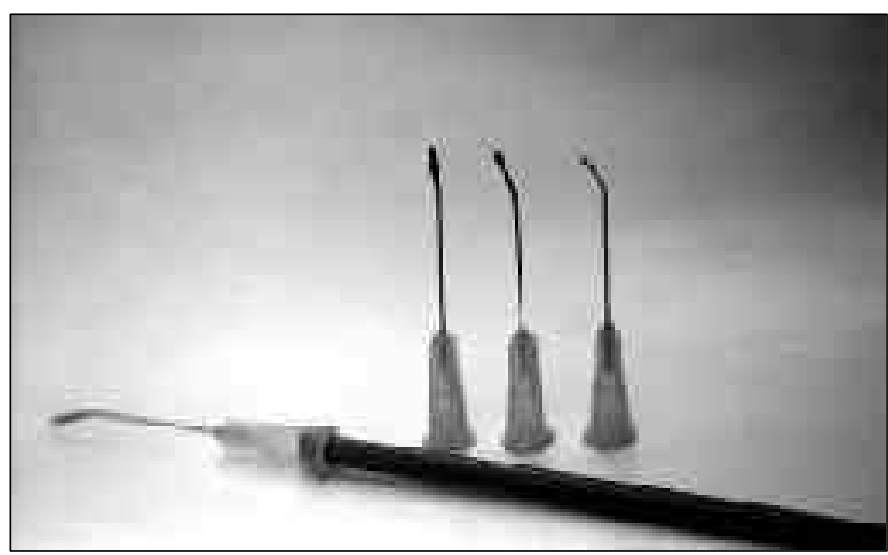

Fig. 5 - Manufacturing process (from right to left), from the cannula, through square-sharp, and rough design, until the mounted instrument

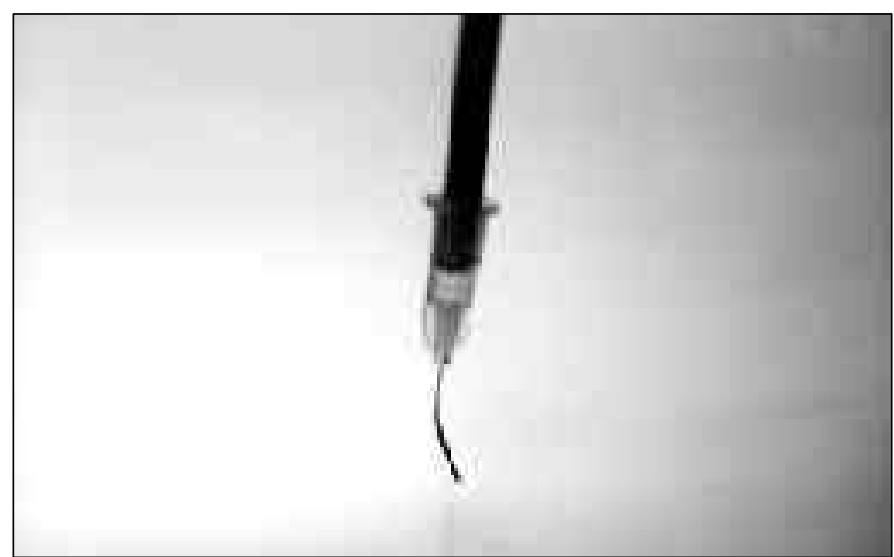

Fig. 6 - Instrument flexibility under applied low pressure

be taken not to cut the agar, this limitation did not interfere with the culture results. Moreover the microscopic smear appearance was similar to current technique. 


\section{DISCUSSION}

We have been using this instrument for almost 2 years in the Ophthalmology Department of the Federal University of São Paulo and the Ophthalmos Microbiology Laboratory. Several hundred corneal lesions were cultured and submitted to direct observation, resulting in adequate smears.

The devices are being sent to satellite laboratories and offices, that may scrap the cornea at a low coast, and due to the easy availability and physical properties (i.e. flexibility and delicate manipulation - Figure 6), it may be used to remove foreign bodies, keratoconus scars, scrap the epithelium before PRK and lift the LASIK flap.

\section{RESUMO}

Os autores descrevem um novo método para produzir um instrumento para colheita de material de córnea. Tal ins- trumento pode ser manufaturado com uma cânula ou agulha fina. O material é moldado de forma plana com o auxílio de um laminador, ou de um martelo e placa de metal. Lixa fina é utilizada para arredondar as bordas e a ponta é ligeiramente dobrada. Um cabo pode ser adicionado de modo a facilitar a manipulação do instrumento, que pode ser reutilizado após lavagem e esterilização local na ponta do metal, ou por óxido de etileno.

Palavras-chave: Espátula; Microbiologia; Diagnóstico; Bioengenharia; Córnea.

\section{REFERENCES}

1. Hyndiuk RA, Seideman S. Clinical and laboratory techniques in external ocular disease. In: HB Fedukowicz (ed.), External Infections of the Eye (2nd ed.). New York: Appleton-Century-Crofts chapter 5, 1978.

2. Kimura SJ, Thygeson MD. The cytology of external ocular disease. Am J Ophthalmol 1955;39:137-45.

\section{$5 \circ$ SIMPÓSIO INTERNACIONAL DE UVEÍTES}

\section{6 a 28 de março de 2.000 - Buenos Aires - Argentina}

\section{Simpósio organizado pelo Grupo Internacional de Estudos em Uveítes (IUSG)}

Contará com a presença de 50 especialistas em uveítes do mundo inteiro.

Os membros da Sociedade Brasileira de Uveítes e do Conselho Brasileiro de Oftalmologia terão destaque especial no congresso.

\section{INFORMAÇÕES:}

No Brasil: Dr. Rubens Belfort Jr.

R. Botucatu, 822 - CEP 04023-062 - São Paulo - SP

Fax: $(55-11) \quad 573-4002$
Na Argentina: Dr. Cristóbal Couto

Fax: (54-1) 953-2092 